\begin{tabular}{|c|c|c|}
\hline 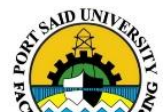 & $\begin{array}{l}\text { Port-Said Engineering Research Journal } \\
\text { Faculty of Engineering - Port Said University }\end{array}$ & \\
\hline 2) & $\begin{array}{llll}\text { Volume } 24 & \text { No. } 1 & \text { March } 2020 & \text { pp: } 128: 140 \\
& (\text { Electrical Engineering) } & \end{array}$ & \\
\hline
\end{tabular}

\title{
Overview of DC and AC Electric Railway Systems Considering Energy Efficiency Enhancement Methods
}

\author{
Mohamed S. Elbelkasi ${ }^{1 *}$, Ebrahim A. Badran ${ }^{1}$, and Mansour H. Abdel-Rahman ${ }^{1}$
}

\begin{abstract}
In this paper, both DC and AC railway electric power feeding systems are reviewed and discussed. The advantages and disadvantages of these systems are also compared. One major problem of such systems is that they take the lion share of electricity consumption compared to non-traction systems. Therefore, most of the new technologies focus on enhancing Energy efficiency of railway systems. This paper discusses the main operation methodologies for reducing the consumption of electric traction systems. These methods include using renewable energy resources (RER), such as solar photovoltaic (PV) panels, wind turbines, and regenerative braking. Moreover, the most common energy storage devices such as batteries, super-capacitors and flywheels. They are used in railway systems for storing the excess energy from RER or the return energy during regenerative braking (Batteries, super-capacitors and flywheels) are also explained. Besides, challenges of the right storage system selection for specific applications are briefly discussed.
\end{abstract}

Keywords: AC railways, DC railways, Traction systems, Renewable Energy, Regenerative braking, Energy Storage System.

\section{Introduction}

From an environmental, social and financial point of perspective, the present transport system [1-2] demonstrates to be unsustainable. Electrical railways are perhaps the most effective, cleanest and safest of all by comparing transport systems. Besides several other benefits such as traffic capacity, power effectiveness, greater power / weight ratio, reduced maintenance and operating costs, fewer noise, electric railway system become popular than other systems [3]. These characteristics make it one of the main elements of future transport systems. However, installation involves considerable capital expenditure [1].

The advancement of railway electric power feeding systems has always been closely linked to the technological advances at the moment. The utility grids were lower and weaker than today at the dawn of railway electrification, and the use of large engines at industrial frequency posed many inconveniences. All of this has resulted in the development of dedicated systems for DC and single phase low frequency AC [1].

With the subsequent advancement of the utility grid and the technological advances attained in the field of electric motors, AC railway systems could be supplied directly by energy transformers. Five main electrification schemes currently exist as a consequence of this development phase: $750 \mathrm{~V}$ DC, $1500 \mathrm{~V}$ DC, $3000 \mathrm{~V}$ DC, $15 / 11 \mathrm{kV} 162 / 3 / 25 \mathrm{~Hz}$ and $25 \mathrm{kV} 50 / 60 \mathrm{~Hz}[4]$.

\footnotetext{
${ }^{1}$ Department of Electrical Engineering, Faculty of Engineering, Mansoura University, Egypt, *m_elbelkasi@mans.edu.eg
}

Transport has a large share of energy consumption, particularly in the case of automobiles. Daily diesel fuel costs are rising. Most countries were not interested in alternative methods for power supply systems when the cost of diesel was very cheap. But new technologies have been developed to enhance the energy efficiency of railway systems after the diesel fuel has been increased to high values [5]. These methods include the use of renewable sources of energy, regenerative braking and energy storage systems [6].

Increasing costs of electrical energy, energy losses in the current electricity grid, dangers of nuclear power generation, and worldwide changes in the environment motivate a conversion of standard ways of producing electricity. Overall, there is a willingness to depend more on renewable energy resources (RER) for electricity generation such as wind and photovoltaic. RERs reduce harmful emissions and may result in economic benefits by applying dynamic pricing on demand side management [7].

Regenerative braking is one of the primary factors for increasing the attained rates of energy efficiency in electric railway systems. The traction motor operates as a generator during regenerative braking and supplies some of the stored kinetic energy to the power source or an energy storage system [6].

Energy storage techniques used in the rail sector primarily to enhance the efficiency of the regenerative brake scheme and to store excess energy from renewable sources [6]. Batteries, super-capacitors and flywheels are the three most commonly used storage systems. Superconductive energy storage [8] and fuel cells are also used other than the three listed [9-11]. 
The rest of the paper is organized as follows, the design, construction, and testing of railroad vehicles, including locomotives and rolling stock are presented in Section 2. Different traction feeding systems are discussed in section 3, while the rail maintenance procedures are illustrated in section 4. Section 5 focuses on enhancement methods of railway energy efficiency. The conclusion of this paper is presented in section 6 .

\section{Design, construction, and testing of railroad vehicles}

\subsection{Light Rails}

Light-rail trains, which usually have few cars up to three, have very short distances between sub-stations, which are often a mile or two. Therefore, they require rapid acceleration and stoppage. These trains have low power requirements, usually a fractional megawatt. Thus, they can be easily fed from a DC system with low voltage. The consequences stops are 2-3 miles apart and are generally permitted to be located near the train station $[5,12]$.

\subsection{Commuter and Intercity Trains}

Commuter trains are generally lengthy trains that serve suburban regions and travel at high speeds up to 125 miles per hour. These trains have greater energy requirements and are supplied from catenary systems with high voltages range from $15 \mathrm{kV}$ to $25 \mathrm{kV}$. The stops of such trains are separated by a longer distance than light rail trains (5-10 miles). These longer distances provide time to the train to reach greater speeds up to 125 miles per hour if the track situation and allowed speed limit allows such high speeds. These trains can be supplied from various alternative technologies, requiring more power quality factors, etc. The energy requirement is 3 to $4 \mathrm{MW}$ [5].

The intercity trains provide higher speeds and they are sometimes with more carriages. Therefore, the demand for energy is greater. These trains don't need to stop frequently because of the very long distances between cities. The demand for power can range from 3 to $4 \mathrm{MW}$ anywhere. The energy demand for these trains can be provided from $69 \mathrm{kV}, 115 \mathrm{kV}$ or $220 \mathrm{kV}$ systems for a standard railway traction station [12].

\subsection{High-Speed Trains}

France's TGV trains (Train à Grande Vitesse, is France's intercity high-speed rail service, operated by the SNCF, The société nationale des chemins de fer français is France's national state-owned railway company) are considered among the world's fastest trains. TGV trains operate up to a top speed of 330 miles per hour, thus requiring much greater energy. In France, the TGV trains work at peak hours with 5 minutes of headway. The system was intended for 4 minutes headway operation. For their standard railway system, $\mathrm{SNCF}$, the French railway, utilizes a single phase $25 \mathrm{kV}$, $50 \mathrm{~Hz}$ scheme, but utilizes a $+/-25 \mathrm{kV}$ auto-transformer system for these trains. The French national grid, supplies the energy to the traction power sub-station, and this traction load of the TGV or main commuter system is fed only at $275 \mathrm{kV}$ or $400 \mathrm{kV}$ from the high voltage systems. This gives their other clients more reliability and decreases power quality problems. The electrical system is intended to lose a sub-station [5].

\subsection{Freight Trains}

The demands of this type are much greater. Although freight trains are running slowly (less than 80 miles per hour), they are using much more tractive energy. Freight train sets differs greatly between nations. Their electrified railway tracks are similar to those used for commuter and intercity trains in most nations in Europe or the remainder of the world. The power requirements range from 4 to 8 MW. Four to six diesel locomotives haul freight trains in the US. Compared to single stacks all over the world, US freight rails use double stack freight trucks. Longer train sets (with more than 100 carriages) are used by freight trains needing high power in the range of 18-24 MW [5].

Railway electrification systems and loads needed for light rails, commuter trains, high-speed trains and freight trains are all different. Power requirements differ greatly from one of these distinct railway systems to another. Therefore, choosing a suitable electrification system depends greatly on the objectives of the system. Table 1 shows the typical power requirement for all mentioned railway trains [12].

Table 1 Power demand for various railway trains [12]

\begin{tabular}{|c|c|c|}
\hline Train System & Power Demand & Classification \\
\hline Light & $>1 \mathrm{MW}$ & Low \\
\hline Commuter & $4-6 \mathrm{MW}$ & Medium \\
\hline High speed & $6-10 \mathrm{MW}$ & High \\
\hline Freight & $18-24 \mathrm{MW}$ & Very High \\
\hline
\end{tabular}

\section{Railway electric power feeding systems}

A huge variety of electrical traction systems exist all over the world that were built based on railway type, its location and the technology accessible at installation period. Seen today, many installations were constructed up to 100 years ago for the first time. In the last 20 years, there has been a huge acceleration in the growth of railway traction due to the huge benefits of electrical power supply compared to diesel fuel [5].

In the railway industry, electrical power technology relates to the means of providing the electric motors with good quality electrical power. It consists primarily of power conversion technology at sub-stations, feeding circuits for DC and AC feeding systems, and electrical overhead lines structure, materials, measurement and maintenance [13]. 
Table 2 demonstrates different feeding systems worldwide and the distances of electrification. Electric operation on railroads with many lengthy tunnels or subterranean railroads is often preferred because the power effectiveness is greater than steam or diesel engines and does not require onboard combustion. The elevated tractive force also makes electrical operation appropriate for hilly lines. As a result, there has been notable progress in electric train operation. It began with DC feeding systems that could directly drive a DC motor, offer elevated tractive force and provide a more simple speed control. While a 3000-V DC feeding scheme is commonly utilized in many nations, some Japanese railways utilize a $1500 \mathrm{~V}$ DC system [13].

The other AC feeding scheme was produced with a single phase, commutator type engine in Europe. To minimize the failures of rectification, special low frequencies such as 25 $\mathrm{Hz}$ and $16.66 \mathrm{~Hz}$ have been implemented in many nations including Austria and Germany [13]. Subsequent evelopments in silicon commutator technology paved the way for $\mathrm{AC}$ feeding systems in France and elsewhere using commercial frequencies [13]. The $25 \mathrm{kV}$ system is commonly used worldwide, while Japan relies on a shinkansen $25 \mathrm{kV}$ scheme and a 'conventional' railway $20 \mathrm{kV}$ AC feeding scheme. The 3phase, AC feeding scheme is used with steep-mountain-grade induction motors in Europe, while a $600 \mathrm{~V}$ system with power converter speed control is used for new urban transit schemes in Japan [13].

Around the globe, several distinct electrification systems are in use. Three primary parameters classify electrification systems [14]:

$$
\begin{aligned}
& \text { * The operating voltage } \\
& \text { The current } \\
& \text { - Direct current } \\
& \text { - Alternating current } \\
& \text { * The Contact System } \\
& \text { - Overhead line (catenary) } \\
& \text { - Third rail }
\end{aligned}
$$

\begin{tabular}{|c|c|c|c|c|c|c|c|}
\hline & \multirow{2}{*}{\multicolumn{2}{|c|}{ System Type }} & \multicolumn{2}{|c|}{ Japan1 } & \multicolumn{3}{|c|}{ World (Japan included) } \\
\hline & & & km & $\%$ & km & $\%$ & Major Countries \\
\hline \multirow{3}{*}{$\begin{array}{c}\text { Direct } \\
\text { current } \\
(\mathrm{V})\end{array}$} & \multicolumn{2}{|c|}{$V<1,500 \mathrm{~V}$} & $0.915 \times 10^{3}$ & 5.0 & $5.106 \times 10^{3}$ & 2.0 & $\begin{array}{l}\text { USA, UK, Germany, and } \\
\text { Switzerland. }\end{array}$ \\
\hline & \multicolumn{2}{|c|}{$1,500 \leq V \geq 3,000$} & $10.484 \times 10^{3}$ & 61.0 & $22.138 \times 10^{3}$ & 9.0 & $\begin{array}{l}\text { Australia, Netherlands, Spain, } \\
\text { and France. }\end{array}$ \\
\hline & \multicolumn{2}{|c|}{$V \geq 3,000$} & & & $78.276 \times 10^{3}$ & 33.0 & $\begin{array}{l}\text { South Africa, Italy, Russia, Spain, } \\
\text { and Poland. }\end{array}$ \\
\hline \multirow{7}{*}{$\begin{array}{c}\text { Single } \\
\text { phase } \\
\mathrm{AC} \\
(\mathrm{KV})\end{array}$} & \multirow{4}{*}{$\begin{array}{c}50-60 \\
\mathrm{HZ}\end{array}$} & $\leq 20$ & & & $0.245 \times 10^{3}$ & 0.0 & USA and France \\
\hline & & 20 & $3.741 \times 10^{3}$ & 22.0 & $3.741 \times 10^{3}$ & 2.0 & \\
\hline & & 25 & $2.037 \times 10^{3}$ & 12.0 & $84.376 \times 10^{3}$ & 36.0 & $\begin{array}{l}\text { China, Russia, India, Romania, } \\
\text { and France, }\end{array}$ \\
\hline & & 50 & & & $1.173 \times 10^{3}$ & 0.0 & South Africa, Canada and USA \\
\hline & \multicolumn{2}{|c|}{$\begin{array}{c}25 \mathrm{HZ} \\
11 \leq \mathrm{V} \geq 13\end{array}$} & & & $1.469 \times 10^{3}$ & 1.0 & Norway, Austria, and USA \\
\hline & \multirow{2}{*}{$\begin{array}{l}16.66 \\
H Z\end{array}$} & 11 & & & $0.12 \times 10^{3}$ & 0.0 & Switzerland \\
\hline & & 15 & & & $35.461 \times 10^{3}$ & 15.0 & $\begin{array}{l}\text { Switzerland, Sweden, and } \\
\text { Germany, }\end{array}$ \\
\hline \multicolumn{3}{|c|}{ Three-phase } & $0.03 \times 10^{3}$ & 0.0 & $0.043 \times 10^{3}$ & 0.0 & France and Switzerland \\
\hline \multicolumn{3}{|c|}{ unrecognized } & & & $3.668 \times 10^{3}$ & 2.0 & France and Kazakhstan \\
\hline \multicolumn{3}{|c|}{ Sum } & $17.207 \times 10^{3}$ & 100.0 & $235.816 \times 10^{3}$ & $\overline{100.0}$ & \\
\hline
\end{tabular}

Table 2 World systems for the feeding of electric railways and electrified distances [13]

\subsection{Standardized Voltages}

For European and international standardization, six of the most frequently used voltages were chosen. These voltages do not depend on the contact system used so a $750 \mathrm{~V}$ DC, for example, can be used on third rail and overhead lines which are usually used by trams. Many other voltages are used around the globe for feeding railway systems, and the list of present electrical rail traction systems includes both standard and non-standard voltage systems is presented in Table 3. As mentioned in BS EN 50163 and IEC 60850 standards, the maximum allowed voltage range for standardized voltages.
These take into consideration the amount and distance from the sub-station of trains drawing current [15].

The electricity produced by power stations is transmitted via transmission lines to electric railway sub-stations. For direct-current electric railways, the receiving voltage at substations is generally extra-high voltage at $22 \mathrm{kV}, 66 \mathrm{kV}$, or 77 $\mathrm{kV}$. This is transformed by a transformer to $1200 \mathrm{~V}$, and then by a rectifier to direct current at $1500 \mathrm{~V}$ rated voltage $(1620 \mathrm{~V}$ non-load voltage). Using 600 or $750 \mathrm{~V} \mathrm{dc}$, in subways and certain private railways [13].

The receiving voltage is an extra-high voltage of $66 \mathrm{kV}$, $77 \mathrm{kV}, 110 \mathrm{kV}$, or $154 \mathrm{kV}, 220 \mathrm{kV}$, or $275 \mathrm{kV}$ for alternativecurrent standard electric railways. A feeding voltage of $20 \mathrm{kV}$ 
is used by standard railways and some private railways use single phase at $25 \mathrm{kV}[13]$.

Table 3 Electrical rail traction systems includes standard voltage systems as well as non-standard voltage systems [15]

\begin{tabular}{|c|c|c|c|c|c|}
\hline $\begin{array}{c}\text { Traction } \\
\text { system }\end{array}$ & $\begin{array}{c}\text { Non-Permanent } \\
\text { Lowest Voltage } \\
(\boldsymbol{k V})\end{array}$ & $\begin{array}{c}\text { Permanent } \\
\text { Lowest voltage } \\
(\boldsymbol{k} V)\end{array}$ & $\begin{array}{c}\text { Rated Voltage } \\
(\boldsymbol{k V})\end{array}$ & $\begin{array}{c}\text { Permanent } \\
\text { Highest Voltage } \\
(\boldsymbol{k V})\end{array}$ & $\begin{array}{c}\text { Non-Permanent } \\
\text { Highest voltage } \\
(\boldsymbol{k V})\end{array}$ \\
\hline DC - 600 V & 0.4 & 0.4 & 0.6 & 0.72 & 0.8 \\
\hline DC - 750 V & 0.5 & 0.5 & 0.75 & 0.9 & 1 \\
\hline DC - $1500 \mathrm{~V}$ & 1 & 1 & 1.5 & 1.8 & 1.95 \\
\hline DC - 3000 V & 2 & 2 & 3 & 3.6 & 3.9 \\
\hline $\begin{array}{c}\text { AC }-15 \mathrm{kV} \\
16.7 \mathrm{~Hz}\end{array}$ & 11 & 12 & 15 & 17.25 & 18 \\
\hline $\begin{array}{c}\mathrm{AC}-25 \mathrm{kV} \\
50 \mathrm{~Hz}\end{array}$ & 17.5 & 19 & 25 & 27.5 & 29 \\
\hline
\end{tabular}

\subsection{Current}

\subsubsection{DC feeding System}

A 3-phase bridge rectifier is used for conversion from 3phase AC to a DC scheme. Since a 6-pulse scheme is used by the 3-phase rectifier, it creates reduced harmonics in the AC side and distortion in the waveform of the voltage, reducing the power quality. Currently, two sets of 6-pulse rectifying scheme are used to form a 12-pulse scheme. The two sets can be connected in series or parallel with a phase shift of $30^{\circ}$ between the AC input voltages. Such configuration is beneficial for decreasing the harmonics. Figure 1 is an instance of the DC feeding circuit structure connected to the closest sub-station. Section and tie posts are sometimes used to avoid falls in voltage on double tracks where sub-stations are far apart. In this case, a high-speed circuit breaker connects the up and down tracks. On metropolitan trunk lines, the distance between sub-stations is about $5 \mathrm{~km}$ and on other lines is about $10 \mathrm{~km}[13]$.

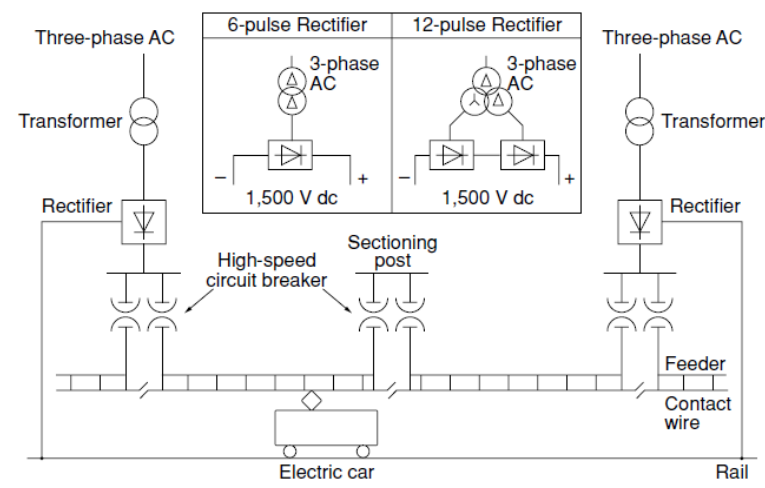

Figure 1 Structure of a DC feeding system

To identify the right positions of sub-stations on the railway system, a thorough assessment is required. The precise position of the sub-station has to be determined after determining the operating voltage $600 \mathrm{~V}, 750 \mathrm{~V}, 1500 \mathrm{~V}$ or $3000 \mathrm{~V}$. This decision is taken on the technical efficiency of the energy scheme, but it is also essential to take into consideration other variables that will determine the final choice, the availability of land, the location of intersections and crossings, the provision of street access to the building's primary gate to facilitate the transport of spare parts of the plant and any required maintenance test equipment [5]. The most economical sub-station distance is shown in table 4.

Table 4 Economical sub-station distances

\begin{tabular}{|c|c|c|c|c|}
\hline Operating Voltage (V) & 600 & 750 & 1500 & 3000 \\
\hline Distance (km) & $3-4$ & $5-6$ & $8-13$ & $20-30$ \\
\hline
\end{tabular}

The voltage distribution for DC Metro and mainline overhead systems are typically $1500 \mathrm{~V}, 3000 \mathrm{~V}$, and therefore require less isolation and clearance compared to $\mathrm{AC}$ electrification. The overhead line conductor's mechanical strength becomes the primary variable in overhead design, making the conductor dimensions between $1500 \mathrm{~V}$ DC not dissimilar and AC $25 \mathrm{kV}$. Where energy demands exceed the overhead catenary capacity, parallel feeds must be included along the overhead masts. To guarantee excellent present sharing, connections are established to the catenary at periodic intervals [5].

To maximize sub-station spacing with $750 \mathrm{~V}$ and $1500 \mathrm{~V}$ $\mathrm{DC}$, the $3000 \mathrm{~V}$ scheme is introduced almost completely to the primary line scheme. Supplies selected primarily for mass transit or light rail systems in urban areas. The factors affecting the spacing of the sub-station $[16,17]$ are:

- Maximum voltage drop allowed

- Loading of the system

- Conductor section

- Tripping current of the circuit breaker

With the DC lower systems voltages, traction energy feeding arrangements are usually applied either at track level (light rail heavy metro systems) or via overhead line (road trains). [5].

For surface lines insulation issues, the third rail system is generally cheaper, the system voltage is $600 / 750 \mathrm{~V}$ on the third rail. The positive conductor in the fourth rail system has a potential of $+400 \mathrm{~V}$ and the negative or fourth rail is -230 
$\mathrm{V}$, this is a $630 \mathrm{~V}$ system. In order to minimize stray traction leakage currents, underground structures use a fourth rail to perform the return current. Without the fourth rail, these leakage currents would result in electrolytic action to corrosion buried water and gas pipes. The center earth system minimizes system voltage to earth, thus decreasing the danger of electrical shock injury $[5,16]$.

Using electrical power for traction applications naturally includes power transmission over significant distances; clearly, using a high voltage can best achieve this. The voltage can be improved when the contact system is positioned overhead and the risk to customers is significantly decreased. A higher spacing of the sub-station is feasible as well as an enhanced system efficiency due to decreased copper losses (If the voltage is doubled then the current is halved for the specified energy, thus reducing copper losses to one quarter) [16].

In order to decrease weight and save energy, efforts are being created to implement regenerative vehicles on DC electric railways. They are intended during deceleration to convert the kinetic energy into electrical power and return it to the overhead lines. But, if there are no cars in the section to use it, the regenerated power would be wasted. Thyristor rectifiers, thyristor inverters, thyristor chopper resistors, or simultaneous up and down feeding schemes can prevent this loss. On some areas, such devices are used. Figure 2 demonstrates a thyristor inverter instance. The motive power is supplied from a rectifier in this system and, if the regenerative power exceeds the motive power requirement, the inverter is automatically enabled to supply power to stations, etc. [13].

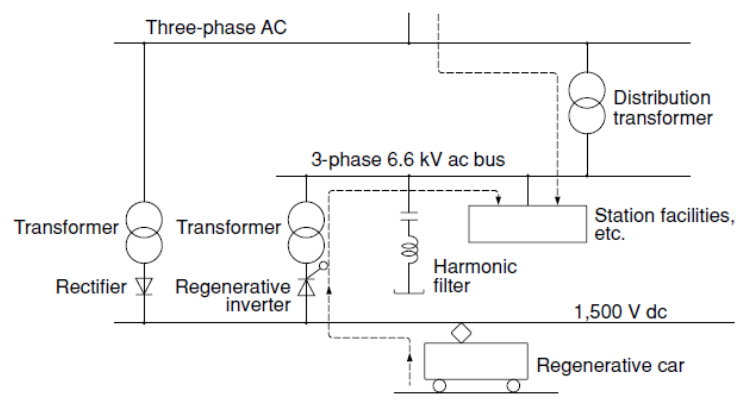

Figure 2 Power regeneration by thyristor inverter

\subsubsection{AC Feeding Systems}

AC electrical distribution to trains is cost-effective for high-speed and heavy-duty railways. The elevated catenary voltage means reduced currents and power losses, thus requiring fewer sub-stations compared to the DC traction networks of reduced voltage [5].

There are many distinct AC system electrification applications. As usual, that can be divided into three parts of the AC system.

- Low frequency AC system

- Poly phase AC system

- Standard frequency

3.2.2.1 Low Frequency AC System
In Germany, Sweden and many European nations, the lowfrequency traction system has been in service for more than two decades. With the contemporary energy electronics technology available for frequency conversion and the elevated energy quality required by utility energy clients, it is probable that the low frequency scheme will make the traction scheme more efficient and attractive [5].

A low-frequency scheme reduces electrification costs by raising the distance between two consecutive sub-stations and decreasing the cost of modifying civil engineering by decreasing the overhead line voltage from the $25 \mathrm{kV}$ (voltage frequently used in the U.S. at $15 / 20 \mathrm{~Hz}$ ) to $16.5 \mathrm{kV}$. Such a system would allow catenaries to be paralleled between two sub-stations. On the second hand, thereby improving catenaries ' capacities and decreasing power quality and voltage unbalance issues [18]. The different benefits of lowfrequency operation are [5]:

\section{A. Longer Sub-station Beat/Less Sub-station Installations}

The inductive voltage drop in the overhead line systems is reduced by a reduced frequency system. A $15 \mathrm{~Hz}$ scheme would have an inductive voltage drop of approximately one fourth compared to a $60 \mathrm{~Hz}$ scheme, allowing sub-stations to be three to four times the distance compared to a $60 \mathrm{~Hz}$ scheme based solely on the voltage drop criterion. The amount of sub-stations needed might be decreased to 30-40\%.

\section{B. Parallel Catenary Operation from Adjacent Sub-station}

The traction system's overhead lines can be all in phase. On the secondary hand, they can be parallel. Parallel to the secondaries, the energy can be taken from two or more substations, thereby further reducing the voltage drop in the overhead lines and the load is also distributed on two or more sub-stations. As the train moves along, there will be a smoother load shift from one to the other sub-station.

\section{Reduction of Operating Voltage to $15-16.5 \mathrm{kV}$}

Due to the low frequency and parallel operation of the overhead wires system the sub-station beat may be raised, lower overhead line voltage might be used, and significant savings can be accomplished in changes to civil engineering by decreasing the demands for electrical clearance at lower voltage level. The smaller voltages were used successfully in Sweden and Germany. Reducing the voltage level, furthermore, could boost the current in the overhead lines and boost losses that could require an overhead line conductor of greater size or an extra feeder circuit.

\section{Lesser Requirements for Civil Engineering and Electrical Clearance:}

Lower voltages will lead to reduced demands for clearance. This could be helpful if it is necessary to raise bridges, lower tracks, or if the tunnels do not allow appropriate clearances for the $25 \mathrm{kV}$ scheme.

\section{E. Reduction of Voltage Capacity of Sub-station or Better use of Sub-station Capacity and Overhead Line Capacity}

Each substation must be intended with the single-phase, 25 $\mathrm{kV}, 60 \mathrm{~Hz}$, system to provide the trains with complete energy within the sub-station beat and half the adjacent substation. 
Through paralleling the electric railway scheme on the secondary side and exchanging the loads between the adjacent sub-stations, it is really feasible to decrease the capacity of sub-station or provide greater frequency of trains.

\section{F. Reduction of Unbalance Voltage Problems}

The traction loads one of the worst load types because it's sometimes delivered from one or two phases of an electrical system. The single-phase load generates problems of power quality such as unbalance of voltage. The load will appear on the distribution system as a balanced load with a low frequency traction scheme. Little current issues or unbalanced voltage would arise. The conversion frequency scheme would also distinguish load for traction from other clients.

\section{G. Reduction of Harmonics into the System:}

Harmonics would be produced in the conversion equipment with the low frequency scheme. In order to restrict the harmonics to acceptable levels, adequate filtering may be given with the conversion equipment. Modern electric locomotives have correction of the power factor and harmonic filtering on board. The system's frequency conversion equipment filters would further decrease the harmonics produced by locomotive and decrease the harmonics accessing the power system.

\section{H. Lower Voltage Substations for the Utility}

The train-induced unbalance voltage can become the single most significant factor that will dictate the main voltage substation selection. To restrict the substation harmonics and the voltage imbalance, adequate short circuit duty and voltage levels are needed.

\subsubsection{Poly-phase AC System}

Due to the intrinsic regenerative capacity of three-phase induction motors, AC 3-phase transmission, usually the most effective way of distributing high-power electricity, would be beneficial for traction. However, due to the complexity of power collection by moving locomotives, it was not commonly implemented [19].

Many railways used two or three catenaries, generally to bring the current in three phases to the trains. Today, threephase AC current is only used on Switzerland's gornergrat railway and jungfraujoch railway [19], France's petit de la rhune train, and Brazil's corcovado rack railway; it was commonly used in Italy until 1976. The two overhead line conductors are used on these railways for separate threephase AC phases, while the rail is being used for the third phase. There was no use of the neutral $[19,20]$.

Three overhead wires were used by some three-phase AC railways. These were siemens ' experimental railway line in Berlin-Lichtenberg in 1898 (length:1.8 km), the military railway between Marienfelde and Zossen between 1901 and 1904 (length: $23.4 \mathrm{~km}$ ) and an 800-meter-long section of a coal railway close Cologne from 1940 to 1949 [21].

\subsubsection{Standard Frequency System}

Only in the 1950s after growth in France, in spite of the simplification of a distribution scheme that can use the current network power supply, did the conventional frequency singlephase alternating current scheme become common [5, 21].

The AC of $25 \mathrm{kV}, 50 / 60 \mathrm{~Hz}$ electrification system was specifically created for the purposes of railway traction. The primary characteristic that distinguishes this scheme from the government supply authority's standard three-phase and neutral HV distribution network is that the railway system is a single-phase, one-pole earthed system [17].

The $25 \mathrm{kV}$ rail network was intended to satisfy the requirements of a quick, intercity, multi-track rail network that frequently carries a range of trains. Such operation needs a catenary system that is extremely secure, reliable for staff and passengers and offers the traction units with a high degree of supply safety. This safety will guarantee that the traction supply system can provide the energy concentrations needed to satisfy the traction unit output. It should be acknowledged that the electrification system reliability should be checked if the service or loads are improved [17].

This system is very economical, but it has its disadvantage s: the external power system phases are unequally loaded, and major electromagnetic interference is produced and acoustic noise [21].

The practical details of AC power feeding are about maintaining supply quality. On the traction side, catenary feeding systems have been developed using feeding booster transformers and feeding auto transformers to improve transmission efficiency and regulate the system and reduce earth [19, 21].

\section{A. Booster Transformer Feeding System}

A booster transformer (BT) is located on the contact wire every $4 \mathrm{~km}$ to raise the current on the negative line of the return circuit. Figure 3 shows a BT feeding circuit's composition [13].

Using this BT design reduces inductive interference on telecommunications lines as the current flows only in restricted sections to the rail. In general, a huge arc is created in the section when an electric car passes through a BT section and a high current of load may create a huge arc to harm the catenary [13].

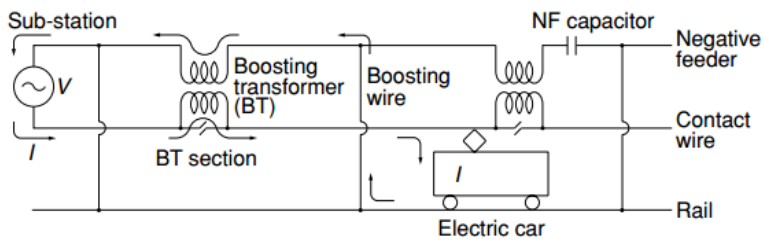

Figure 3 Structure of a BT feeding circuit

\section{B. Autotransformer Power Feeding System}

The electrical current in railways is transferred from the overhead line to the traction load, where electric motors use the energy and the connected rails are fed to the earth that are part of the return circuit. The rail and the earthed return conductor are connected to the midpoint of the catenary autotransformer in a two-phase fed catenary system. One pole of the autotransformer is connected to the catenary phase and the other pole is connected to the negative phase conductor as shown in figure 4 . With this connection, the locomotive is 
supplied with double voltage power compared to the locomotive's own voltage. This means that in comparison with the single-phase feeder, the phase currents are reduced to half and the feeder losses to the fourth part. The autotransformers task along the overhead line is to regulate the voltages between the catenary and the earth and the negative phase conductor and the earth, and then evenly distribute the return current between the two phases.

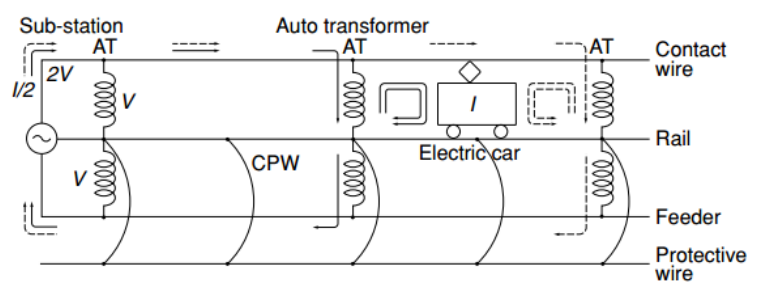

Figure 4 Structure of a BT feeding circuit

Compared to single phase feeding and booster transformers, the advantages obtained with this connection are through the following [5]:

- Low losses owing to increased voltage

- Lengthier distance between substations for overhead

lines feeders

- Good collection of stray currents returning

- Lower communication interference

Autotransformer (AT) feeding combines the advantage of transmitting higher voltage power, thus increasing substation spacing, with the convenience of using standard $25 \mathrm{kV}$ traction equipment. The AT winding is linked between the catenary and an auxiliary feeder and the rails are linked to an intermediate point. The winding has a $1: 1$ ratio in $25 \mathrm{kV}$ traction systems with a center-tapped $50 \mathrm{kV}$ supply on the rails [21].

\subsection{Contact system}

\subsubsection{Overhead Line (Catenary) System}

The power of the electric railway is used for the motors, lighting, and air conditioning. This is taken from the overhead line using the pantograph on the roof. Whether the train is moving or not, the pantograph contacts the overhead line. The
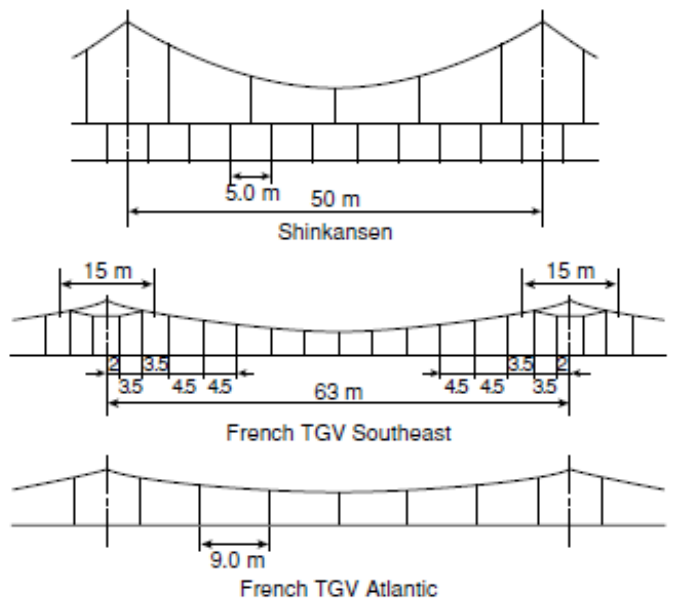

Figure 5 High speed train catenary equipment in various countries pantograph must preserve in contacting with the overhead line for feeding uninterrupted, good power quality at all times [13]. Loss of contacting is undesirable since it can result in arcs that lead to the deterioration of the sinusoidal waveform and causing high-frequency harmonic currents [22]. Therefore, the overhead equipment is designed according to the following [13]:

- Have characteristics to meet requirements of train speed and current.

- Have uniform spring constant of the entire equipment and be at uniform height for optimizing power collecting characteristics of the pantograph.

- Have low vibration for smooth pantograph passage during high-speed operation.

Catenaries can be classified to three types that applied in high speed railway systems: simple, stitch and compound [23]. Simple contact line system is used on the newer lines that links provincial cities, where high density operations are not required [5]. Simple contact line system consists of three basic elements [17, 22]; the messenger wire, the contact wire, and the droppers. The messenger wire supports the cable system. The contact wire supplies the vehicles. The droppers are the vertical cables which are connected electrically and linked mechanically by means of clamps on the messenger and contact wires.

Stitched contact line uses a further wire at each support structure, terminated on either side of the messenger wire. Finally, compound contact line uses a support auxiliary wire between the messenger and the contact wires. Droppers support this auxiliary from the messenger wire. The auxiliary wire is constructed of a conductive and less wear- resistant metal for increasing the efficiency of power transmission [14].

Figure 5 compares high-speed train catenary equipment in various countries. In Japan, three longitudinal wires are used to coast compound catenary equipment for shinkansen, while in Europe, simple or stitched catenary equipment is used. Twin catenary equipment is used by the Italian high-speed line to supply the large current for $3 \mathrm{kV}$ DC electrification [13].

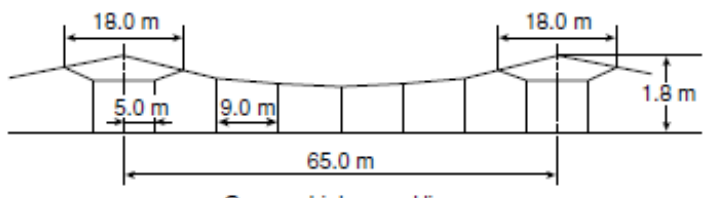

German high-speed line

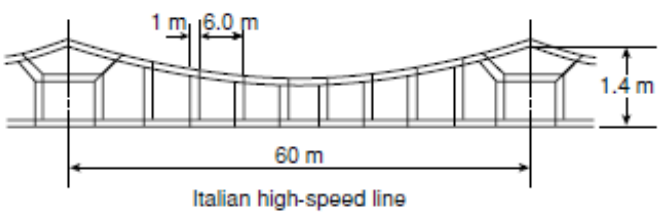




\subsubsection{Third Rail}

A third rail is a method of providing electricity to power a railway along the railway track or between the rails through a continuous rigid conductor. It is typically used in a mass transit or rapid transit system with alignments in its own hallways that are completely or almost completely separated from the external environment [5].

Usually the third rail is outside the two running rails, but sometimes it goes between them. The electricity is transferred to the train through a sliding shoe in contact with the rail. An isolating cover is given on many systems above the third rail to safeguard staff working close the track.; sometimes the shoe is intended to contact the third rail's side (called side running) or the third rail's bottom (called bottom running), enabling the protective cover to be mounted directly on its top surface. It is referred to as top running when the shoe slides on top. When the shoe slides bottom, the build-up of snow or leaves will not affect it $[5,13]$. The structure is shown in Figure 6.

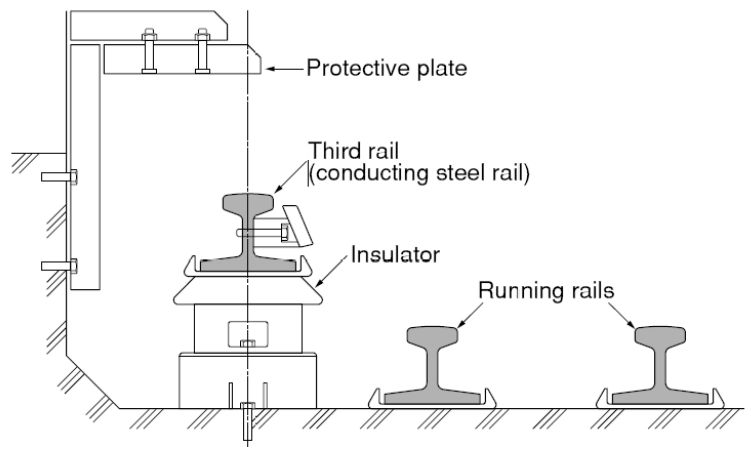

Figure 6 Third rail Structure

There are many third-rail benefits [5]:

\section{i- Cost}

Installation of these systems is cheaper than catenary systems, less susceptible to natural phenomena such as snow and flooding which causes serious problems, and better able to adapt to low vertical clearance areas, such as bridges and tunnels. They have been viewed in many nations as a main means of decreasing tunnel building costs; consequently they are popular for underground trains.

\section{ii- Visual Appear}

Third-rail systems result in less visual intrusion: they do not need overhead lines that are perceived by some as unsightly.

\section{iii- Robustness}

Third-rail systems are more durable than catenary systems because the conductor rail can take on greater mechanical forces than an overhead line system's contact wire. If it strikes the conductor rail too hard, the shoe equipment on a train is intended to shear off, but as a train has many sets of shoe gear, it can precede its trip. By contrast, pantographs are more likely to get tangled in the overhead wires and can't precede their trip.

\section{iv- Maintenance Access}

Because it lies within simple reach close the ground, a third rail system enables simple maintenance instead of many feet up in the air.

\section{v- Compatibility}

Many railways use a third rail and DC power, even where, owing to the high price of retrofitting, overhead lines would otherwise be practical. Any development of such a system must address the compatibility issue. It generally leads to the selection of technology that already exists.

However all those advantages, there are disadvantages of third rail:

\section{i- Safety}

An unguarded electrified rail carrying over 50 volts is a safety risk and some individuals were died by touching or stepping on the rail while trying to cross the tracks. Such incidents, however, are generally the victim's consequence of carelessness. Probably the main danger is linked to level crossings. While their number on third rail lines is usually decreased to none, it still occurs on some systems, especially on the network's rural and suburban portions.

\section{ii- Limited Capacity}

In a third-rail system, a relatively low voltage is required. Otherwise, there would be electricity from the rail to the ground or running rails but the resulting greater current (sometimes over 3000 amperes) results in a more proportional voltage drop per mile, This means that sub-stations for electrical feeders must be set up at frequent intervals (usually no more than $16 \mathrm{~km}$ apart) along the line, raising operating costs.

\section{iii- Infrastructure Restrictions}

At times, junctions and other point work require that gaps be left in the live rail, as do crossings at level. Usually this is not a problem, since most third-rail rolling stock has multiple current collection shoes along the train length, but under certain conditions a train may be "gapped" — stalled with none of its shoes in touch with the live rail. Usually, when this occurs, the train must be shunted back to a live section either by a rescue locomotive or by another service train, although jumper cables may be used in some conditions to momentarily hook train's current collectors to the closest live rail part. It can be a significant cause of disturbance, given that gapping tends to occur at complicated, significant junctions.

\section{iv- Inefficient Contact}

Fallen leaves, snow and other debris on the conductor rail can decrease the contact effectiveness between the conductor rail and the pick-up shoes, leaving trains stalled due to energy shortages.

\section{Track ( maintenance )}

\subsection{Catenary inspection cars}

As the overhead lines are very lengthy, they are subjected to the pantograph's sliding stress and natural phenomena such as snow, rain, and wind. It is also subject to stress. Therefore, owing to corrosion and wear, the overhead lines are a prospective cause of accidents involving broken wires. It takes many hours to repair such accidents, so maintenance is crucial [13].

Maintenance starts with a precise diagnosis of the overhead line's current condition, often carried out from a moving car. For instance, the overhead lines of the Shinkansen are checked every 10 days using 'Doctor Yellow' an electrical 
seven-car facility and a diagnostic tracking system [13]. A two-car system is used by conventional lines. The measured items include the height of the contact wire above the rail, deviation, wear, pantograph head acceleration, and loss of contact. For Shinkansen, a central computer processes the measured information and sends the outcomes to the corresponding maintenance crews. It is not possible to check certain products from a moving car. These include feeding wires corrosion and loose screws that are manually inspected during normal maintenance work [13].

If lines need to be replaced, special cars are used to carry out the task. For railway engineers, automatic diagnosis and repair is a latest topic and thus unique attempts are being exerted to develop robots for this purpose.

\subsection{Robotics}

Dangerous work at height is required for overhead line systems. A self-powered feeding line robot was developed and commissioned to find cross-sectional area loss due to corrosion with eddy current sensors [13].

\section{Enhancing System Energy Efficiency}

Most of the electrical traction system involves very high energy and high voltage, therefore, the primary issue or concern is power quality. By analyzing railway energy consumption, more than $70 \%$ of the consumption corresponds to traction requirements while the remainder corresponds to non-traction [24]. As a result, most of the latest techniques focus on decreasing the energy consumption associated with traction. A major method for this purpose is to use RER (solar Photovoltaic panels and wind turbines) [25] in traction systems, also using energy Storage Systems (ESS) to store some of kinetic energy during regenerative braking process [26].

Regenerative braking is one of the primary factors for increasing the attained rates of energy efficiency in electric railway systems. The traction motor operates as a generator during regenerative braking and supplies some of the stored kinetic energy to the power source or an energy storage system. Otherwise, the energy retrieved will be converted into heat to the environment if there are no customers for the energy produced or the energy storage system is completed [6].

Since the beginning of the 20th century, Electric Railway Systems (ERSs) has been extensively developed, including sophisticated energy infrastructure for high-speed trains and metro today. Renewable energy demand is continuously increasing owing to worldwide changes in the environment and increasing energy costs. The current power grid depends greatly on conventional electricity generation units based on fossil fuel. Transmitting electrical energy from these generation plants to the customers through transmission lines in today's electricity grid results in significant power losses. Furthermore, the hazards of fossil fuel based generation plants have resulted in a global push from these conventional units towards RERs. By using RERs, it is possible to reduce CO2 emissions worldwide. Furthermore, RERs can allow economic advantages for both clients and utilities through the use of demand side management to dynamically adjust energy prices so that the load between fossil-fuel plants and RERs can be shared judiciously [27]. In order to reduce the carbon footprint of current and future ERSs, there is an unremitting trend towards the introduction of renewable energy (REs) primarily wind and solar energy into these infrastructures. Taking benefits of the current ability of Energy Storage Systems (ESS) to store excess energy. This new technique generates various operational scenarios that add complexity to the creation of satisfying solutions for energy management [28].

\subsection{Energy Storage System}

Energy storage techniques are split into two categories: on-board (OESS) and stationary (SESS) energy storage systems. OESSs are the ones which are installed inside the train while SESSs are installed in the sub-stations. The energy capacity of SESSs is higher than OESSs because the later stores only one train's recovered energy. Nevertheless, OESSs should be able to meet the maximum power produced during the break and the train itself's energy demand [12]. In choosing an OESS device, critical variables include the sizing of the storage device and safety problems, particularly on passenger trains. On-board railway cars can be used for three primary reasons: reducing energy consumption, reducing peak power and running catenary-free [29].

OESS, particularly when heavy haul trains are considered, are not always an economical or technical feasible. SESSs can give a better option in such cases [30]. SESS should have a greater energy capacity compared to an on-board one; on the other hand, there is more freedom to size the system. A stationary storage system with a long life cycle of charging / discharging should have both high power and energy capacity [31].

Batteries, super-capacitors and flywheel are the three most commonly used storage systems.

\section{A- Batteries}

Nickel Cadmium (Ni-Cd): This mature battery technology has a long life, is regarded highly reliable, has low selfdischarge, high robustness, and can resist a wide working variety of temperatures, making it ideal for applications with heavy-duty. Its primary constraints are memory impact and being an environmentally hazardous material, therefore, a significant issue is the final elimination of these batteries [6].

Nickel-Metal Hydride (Ni-MH): This battery type has the same positive electrode and electrolyte as $\mathrm{Ni}-\mathrm{Cd}$, but instead of cadmium it uses hydrogen in the adverse electrode. As a result, batteries with $\mathrm{Ni}-\mathrm{MH}$ are much environmentally safe compared to batteries with $\mathrm{Ni}-\mathrm{Cd}$. In addition, this type has higher energy density, higher specific energy and less memory-effect level than $\mathrm{Ni}-\mathrm{Cd}$ batteries. The primary constraints of Ni-MH batteries are being overheated in case of overcharging and producing hydrogen, which may cause dangerous fires, and thus requiring the use of complicated charging circuits. In addition, when discharging process is conducted at high current, such as in heavy transport applications, their lifetime is considerably decreased (200-300 cycles) [32]. 
Lithium-Ion (Li-Ion): Nowadays, this type is commonly used for portable electronics and electric vehicle due to its cost reduction in manufacturing and strong rewards for cleaner transportation. It has many advantages over $\mathrm{Ni}-\mathrm{Cd}$ and $\mathrm{Ni}-\mathrm{MH}$ batteries such as long life time, high voltage, high power density, no memory effect and less environmental problems. Therefore, it has substituted Ni-Cd and Ni-MH batteries. On the other hand, its expenses are very high, thus many efforts are exerted during manufacturing to considerably reduce its cost [32].

\section{B- Super-capacitors}

Super capacitors store energy in a double layer of electrochemical. Its specific power is significantly greater (500-10000 W/kg) compared to batteries, but its specific energy is significantly lower $(0.2-5 \mathrm{Wh} / \mathrm{kg})$. Their application in traction systems includes power aid during acceleration and climbing and storing excess energy during regenerative braking [33]. They can also form a hybrid system with other electrical ESS especially Li-Ion systems to provide high specific power and energy [6].

\section{C- Flywheels}

They are used in order to store kinetic energy using the moment of inertia of a moving rotor. The main function of the rotor is maximizing energy density while preserving all components' structural integrity under rotational and thermal stress. Some rotors use heavy materials providing low speed but they offer low cost while some others use specific materials to achieve high speeds in the range from 10000 and $100000 \mathrm{rpm}$ with disadvantages of high maintenance costs and weight [34]. The main features of flywheels are high life time, high efficiencies up to 80 percent for round trips, environmental friendly and fast response.

\subsection{Application of different energy storage system}

Table 5 indicates the features and the applications of the three mentioned ESS which is used in traction systems to maximize the benefits of regenerative braking.

Table 5 Application of energy storage system

\begin{tabular}{|c|c|c|c|}
\hline & Batteries & Super capacitors & flywheels \\
\hline Features & $\begin{array}{l}\text {-Less voltage fluctuations. } \\
\text {-Low self-discharge rates. } \\
\text {-Higher capability of energy. } \\
\text {-Cheaper than super capacitors. } \\
\text {-Shorter life cycle compared to super- } \\
\text { capacitor. } \\
\text {-High power loss at low temperatures } \\
\text { (li-ion battery may lose up to } 80 \% \text { of } \\
\text { its discharge power at }-20^{\circ} \mathrm{C} \text { ). }\end{array}$ & $\begin{array}{l}\text {-Extremely high power } \\
\text {-Long lifecycle } \\
\text {-low price } \\
\text {-Reduce costs of cooling and } \\
\text { air conditioning [36] } \\
\text {-Lower energy capacity }\end{array}$ & $\begin{array}{l}\text { - Fast response within } 5 \mathrm{~ms} \text { (switching } \\
\text { between motoring and generation } \\
\text { mode). } \\
\text {-Minimal maintenance } \\
\text {-More beneficial than batteries for on } \\
\text { board heavy haul locomotives } \\
\text { applications [41]. }\end{array}$ \\
\hline applications & $\begin{array}{l}\text {-More appropriate for SESS rather than } \\
\text { OESS } \\
\text { - Used for hybrid cars } \\
\text { - Main source for long distance } \\
\text { catenary free operation of modern } \\
\text { EMUs (Electric Multiple Units) } \\
\text {-Can be hybridized with super } \\
\text { capacitors for urban transportation } \\
\text { application }\end{array}$ & $\begin{array}{l}\text {-Used on board electric trains } \\
\text { as a secondary source of } \\
\text { energy. } \\
\text {-Used for electric vehicles EV } \\
\text { and hybrid electric vehicles } \\
\text { HEVs for urban railway } \\
\text { application. } \\
\text {-Used as SESS. } \\
\text {-Used on a diesel multiple } \\
\text { units DMUs (resulted in } 44 \% \\
\text { fuel reduction) [35]. }\end{array}$ & $\begin{array}{l}\text {-Used as SESS (energy saving of } 12 \\
\text { precent in japan) [35]. } \\
\text {-Used as SESSs in DC light railway } \\
\text { systems } \\
\text { (resulted in } 21.6 \% \text { and } 22.6 \% \\
\text { enhancement in power effectiveness for } \\
\text { single and multiple train operations) } \\
\text { [38]. } \\
\text {-Used as OESS. } \\
\text {-Flywheels of } 1 \mathrm{MW} \text { and } 300 \mathrm{Kw} \text { were } \\
\text { also used for DC metro lines in the UK } \\
\text { and the US. }\end{array}$ \\
\hline
\end{tabular}

\subsection{Challenges of energy storage selection}

Gathering the regenerated energy in a particular application starts with selecting the correct storage system then these systems should be optimally used. This optimization process can be categorized into three steps; locating, sizing and controlling charging / discharging process. Locating the ESS is the first optimization step to discover the correct place for installing it. Secondly the optimal capacity of ESS power and energy is determined. Finally the system must be optimally operated by controlling the charging / discharging process [43]. The target of this final phase is to 
maximize the collected energy collected and minimize the loss. It can be coupled with the issue of train optimum operation [44]. In case of OESS, this phase implies finding the most appropriate moments for charging and discharging so as to maximize the produced energy and/or minimize energy usage. In the event of catenary-free operation, the problem is more important.

\section{Conclusion}

This article presents various traction feeding schemes in detail. Electrification systems with low traffic frequency may be infeasible especially when regenerative braking is used, as lower train running costs can be overcome by higher maintenance costs. Because of the comparatively low frequency of trains, the majority of long lines in many developing countries have not been electrified.

This article also focuses on railway energy efficiency improvement techniques (regenerative braking and renewable energy). In this article, three main storage devices (batteries, super capacitors and flywheels) were provided as SESSs and OESSs. In addition, some latest applications of these storage technologies have been reviewed. For light rail vehicles, super-capacitors are mostly used as OESS and EMUs as a secondary source of energy. Li-ion batteries are used by the only two catenary-free EMUs. Flywheels are found to be much more useful for OESS in the event of heavy haul trains, mostly because of their greater energy and longer service life. It is noted that all three storage systems are used as SESS.

\section{References}

[1] D. S. Jiménez, L. Abrahamson, S. C. Solís, and J. S. Feito, "Electrical Railway Power Supply Systems: Current Situation and Future Trends", International Journal of Electrical Power \& Energy Systems, Vol. 92, pp. 181192, Nov. 2017.

[2] P. Radanne, E. Briquet, and K. Xie, "A Sustainable Future for Transport", Green European Foundation, Vol. 5, Mar. 2011.

[3] H. Lee, G. Kim, S. Oh, G. Jang, and S. Kwon, "Fault Analysis of Korean AC Electric Railway System", Electric Power System Research, Vol. 76, Issue 5, pp. 317-326, Mar. 2006

[4] A. Steimel, "Power-electronic Grid Supply of AC Railway Systems", 13th International Conference on Optimization of Electrical and Electronic Equipment (OPTIM), Brasov, Romania, pp. 16-25, July 2012.

[5] B. Kurdak, "A Single Phase PLL Based Active Power Filter Solution For power Quality Problems in Railway Electrification Systems using Scott Transformer", Thesis, Cukurova University, Institute of Natural and Applied Science, 2010

[6] N. Ghaviha, J. Campillo, M. Bohlin, and E. Dahlquist, "Review of Application of Energy Storage Devices in Railway Transportation", The 8th International Conference on Applied Energy - ICAE2016, Beijing, China, Vol. 105, pp.4561-4568, May 2017
[7] M. H. Rehmani, M. Reisslein, A. Rachedi, M. ErolKantarci, and M. Radenkovic, "Integrating Renewable Energy Resources Into the Smart Grid: Recent Developments in Information and Communication Technologies", IEEE Transactions on Industrial Informatics, Vol. 14 , pp. $2814-2825$, Issue 7 , July 2018

[8] A. R. Eastham, D. M. Pringle, and P. R. Austin, "An Assessment of Superconductive Energy Storage for Canadian Freight Railways", Canadian Electrical Engineering Journal, Vol. 7, pp. 3-12, Issue 3, July 1982

[9] T. Yoneyama, T. Yamamoto, K. Kondo, T. Furuya, and K. Ogawa, "Fuel cell powered railway vehicle and experimental test results", European Conference on Power Electronics and Applications, Aalborg, Denmark, PP. 1-10, January 2008.

[10] K. Tsukahara and K. Kondo, "A Study on Methods to Design and Select Energy Storage Devices for Fuel Cell Hybrid Powered Railway Vehicles", IECON 2013 - 39th Annual Conference of the IEEE Industrial Electronics Society, 2013, Vienna, Austria, pp. 4534-4539, January 2014.

[11] A. R. Miller and J. Peters, "Fuel Cell Hybrid Locomotives: Applications and Benefits", Proceedings of the 2006 IEEE/ASME Joint Rail Conference, Atlanta, GA, USA, pp. 287-293, May 2006.

[12] B. Bhargava, "Railway Electrification Systems and Configurations", IEEE Power Engineering Society Summer Meeting, Conference Proceedings, Edmonton, Alta., Canada, Vol. 1, July 1999.

[13] Y. Oura, Y. Mochinaga, and H. Nagasawa,"Railway Electric Power Feeding Systems", Japan Railway\&Transport Review, Vol. 16, pp. 48-58, June 1998.

[14] S. Frey, "Railway Electrification Systems \& Engineering", White Word Publications, First Edition, 2012.

[15] J. K. Srivastava, V. K. Singh and A.K. Singhal, "Review on Railway Traction Power Supply System", Journal of Environmental Science, Computer Science and Engineering \& Technology, Vol. 2, issue 4, pp. 12361250, Nov. 2013

[16] R. D. White, "AC/DC Railway Electrification and Protection", IET Professional Development Course on Electric Traction Systems, pp. 139-187, Nov. 2012.

[17] R.D. White, " AC 25kV $50 \mathrm{~Hz}$ Electrification Supply Design", 7th IET Professional Development Course on Railway Electrification Infrastructure and Systems (REIS 2015), June 2015.

[18] B. Bhargava, "Benefits of a Low Frequency, Low Voltage Railway Electrification System", Proceedings of the 1996 ASME/IEEE Joint Railroad Conference, Oakbrook, IL, USA, May 1996.

[19] R. J. Hill, "Electric Railway Traction II. Traction Drives with Three-Phase Induction Motors", Power Engineering Journal, Vol. 8, Issue 3 , pp. 143 - 152, June 1994. 
[20] R.J. Hill, "Electric Railway Traction. I. Electric traction and DC traction motor drives", Power Engineering Journal, Vol. 8 , Issue 1, pp. 47 - 56, Feb. 1994.

[21] R. J. Hill, "Electric Railway Traction III. Traction Power Supplies", Power Engineering Journal, Vol. 8 , Issue 6 , PP. 275 -286, Dec. 1994.

[22] J. R. J. Octavio, C. S. Rebollo, and A. Carnicero, "The Dependence on Mechanical Design in Railway Electrification", IEEE Electrification Magazine, Vol. 1, Issue 1, pp. 4-10, Sept. 2013.

[23] T. J. Park, B. J. Kim, and Y. Y. Waug, "A Catenary System Analysis for Studying the Dynamic Characteristics of a High Speed Rail Pantograph", KSME International Journal, Vol. 16, Issue 4, pp. 436447, Feb. 2002.

[24] Q. Gu, T. Tang, F. Cao, and Y. Song, "Energy-Efficient Train Operation in Urban Rail Transit Using Real-Time Traffic Information," IEEE Transactions on Intelligent Transportation Systems, Vol. 15 , Issue 3, pp. 12161233, Jun. 2014.

[25] R. Faranda and S. Leva, "Energetic Sustainable Development of Railway Stations", IEEE Power Engineering Society General Meeting, Tampa, FL, USA, pp. 1-6, Jun. 2007.

[26] S. K. Bade, and V.A. Kulkarni, "Analysis of Railway Traction Power System Using Renewable Energy: A Review", International Conference on Computation of Power, Energy, Information and Communication (ICCPEIC), Chennai, India, Nov. 2018.

[27] M. H. Rehmani, M. Reisslein, A. Rachedi, M. ErolKantarci, and M. Radenkovic, "Integrating Renewable Energy Resources into the Smart Grid: Recent Developments in Information and Communication Technologies", IEEE Transactions on Industrial Informatics Vol. 14, Issue 7, pp. 2814 - 2825, July 2018.

[28] J. A. Aguado, A. J. Sánchez-Racero and S. de la Torre, "Optimal Operation of Electric Railways with Renewable Energy and Electric Storage Systems", IEEE Transactions on Smart Grid, Vol. 9, Issue 2, pp. $993-$ 1001, March 2018

[29] M. Steiner and J. Scholten, "Energy Storage on Board of DC Fed Railway Vehicles", IEEE 35th Annual Power Electronics Specialists Conference, Aachen, Germany Vol. 1, pp. 666- 671, June 2004.

[30] V. Gelman, "Energy Storage That May Be Too Good to Be True: Comparison Between Wayside Storage and Reversible Thyristor Controlled Rectifiers for Heavy Rail", IEEE Vehicular Technology Magazine, Vol. 8 , Issue 4 , pp. 70-80, Dec. 2013

[31] H. Takahashi , H. Ikarashi, K. Honda , M. Ando , and Y. Kim, "Lithium Ion Battery Application in Traction Power Supply System", 16th International Power Electronics and Motion Control Conference and Exposition, Antalya, Turkey, pp. 1068-1072, Sept. 2014.
[32] R.J.Brodd, "Batteries for Sustainability: Selected Entries from The Encyclopaedia of Sustainability Science and Technology", book, Springer Science \& Business Media New York, 2012.

[33] L. Guzzella and A. Sciarretta, "Vehicle Energy and Fuel Consumption - Basic Concepts", Vehicle Propulsion Systems, Berlin, Heidelberg: Springer Berlin Heidelberg, , pp. 13-46, 2013

[34] D. Herman, "Comparison of Storage Technologies for Distributed Resource Applications", Electric Power Research Institute, Palo Alto, California, 2003.

[35] A. Okui, S. Hase, H. Shigeeda, T. Konishi, and T. Yoshi, "Application of Energy Storage System for Railway Transportation in Japan", the 2010 International Power Electronics Conference, Sapporo, Japan, pp. 3117-3123, June 2010.

[36] M. Brenna, F. Foiadelli, E. Tironi, and D. Zaninelli, "Ultracapacitors Application for Energy Saving in Subway Transportation Systems", International Conference on Clean Electrical Power, Capri, Italy, pp. 69-73, May 2007.

[37] C. Capasso and O. Veneri, "Laboratory Bench to Test ZEBRA Battery Plus Super-Capacitor Based Propulsion Systems for Urban Electric Transportation", Energy Procedia, vol. 75, pp. 1956-1961, Aug. 2015.

[38] O. Veneri, F. Migliardini, C. Capasso, and P. Corbo, "ZEBRA battery based propulsion system for urban bus applications: Preliminary laboratory tests", Electrical Systems for Aircraft, Railway and Ship Propulsion, Bologna, Italy, pp. 1-6, October 2012.

[39] M. B. Richardson, "Flywheel Energy Storage System for Traction Applications", Proceedings of International Conference on Power Electronics Machines and Drives, Bath, UK, pp. 275-279, April 2002.

[40] H. Lee, S. Jung, Y. Cho, D. Yoon, and G. Jang, "Peak Power Reduction and Energy Efficiency Improvement with The Superconducting Flywheel Energy Storage in Electric Railway System", Physica C, vol. 494, pp. 246249, Nov. 2013.

[41] M. Spiryagin, P. Wolfs, F. Szanto, Y. Q. Sun, C. Cole, and D. Nielsen, "Application of Flywheel Energy Storage for Heavy Haul Locomotives", Applied Energy, vol. 157, pp. 607-618, Nov. 2015.

[42] A. Rupp, H. Baier, P. Mertiny, and M. Secanell, "Analysis of a Flywheel Energy Storage System for Light Rail Transit", Energy, vol. 107, pp. 625-638, July 2016.

[43] T. Ratniyomchai, S. Hillmansen, and P. Tricoli, "Optimal Capacity and Positioning of Stationary Supercapacitors for Light Rail Vehicle Systems", International Symposium on Power Electronics, Electrical Drives, Automation and Motion, Ischia, Italy, pp. 807-812, June 2014.

[44] N. Ghaviha, M. Bohlin, and E. Dahlquist, "Speed Profile Optimization of an Electric Train with On-Board Energy Storage and Continuous Tractive Effort," International Symposium on Power Electronics, Electrical Drives, 
Automation and Motion (SPEEDAM), Ana Capri, Italy, pp. 639-644, June 2016. 